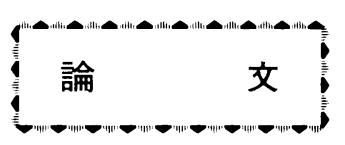

\title{
光計測における二重センサによるノイズ消去法
}

\author{
正会員 嶺 勝 敏* 准 員 勝 田 洋*
}

\section{A method of noise cancelling for an optical instrumentation using a dual-sensor} Katsutoshi Mine (Member) Hiroshi Katsuda (Sub Menber)

(Kyusyu Institute of Technology)

\begin{abstract}
ABSTRUCT
In industrial working condition, signals by an instrumentation with an optical sensor are inaccurate because of noise. If the signal and the noise are separated in the frequency domain, the noise can be reduced by filtering or using a cepstrum.

In this paper, we produced two signals. In order to do this we connected two serial sensors thereby producing one signal. The other signal was produced by connecting the inverse of these two sensors. This method enables us to obtain a reliable signal without any noise on the signal line even if signal and noise could not be separated in the frequency domain. In this case "any noise" means under a quarter frequency of the analog switch.

We propose to call this method alternating Noise Cancelling (ANC). The accuracy of the ANC method has been verified by examples using sinusoidal and other noises.
\end{abstract}

\section{1. ま え がき}

光と放射の物理測定が，第 21 回 CIE 大会の第 2 部門で論じら れている ${ }^{1)}$. 光と放射の測定には, 光電形や焦電形の光センサが 多く用いられるが，光センサの光電変換または焦電変換以前に人 る光学的ノイズ, 背景光の影響が問題となる場合においては, 演 算処理によって補正したり ${ }^{2)}$, 照明環境や雲囲気の変化にともな ら液晶の発色変動を対象と併設した標淮温度一小発生器により補 正する ${ }^{3)}$ 等の研究がなされている. 光センサ及び計測回路自身か らは，電子が粒子であることによる不規則ノイズが発生する ${ }^{4)}$ が，不規則ノイズには，Kalmanフィルタで対応することができ $3^{5)}$.

信号とノイズが加法的に限らず, 乗法的であっても周波数分離 が可能であれば，フィル夕またはケプストラムによってノイズを 除去することができる゙ 。 また，信号とノイズが周波数分離でき ない場合でも，参照ノイズが得られれば適応形ノイズキャンセラ によりノイズを除去するととがでを7，同様に固有ノイズが特定 できれば固有ノイズを除去できる゙ て, 光電変換または焦電変換以後における信号線の伝導ノイズが 信号と周波数分離できないだけでなく, 参照ノイズが得られず固

*九州工業大学工学部奄気工学科

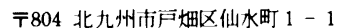

1- 1 Sensiu-cho, Tobata ku, Kitakyushu 804 Japan

本論文の一部は，昭和63年龟気関係学会九州支部連合大会飞て発表済みである。
有ノイズも特定できない場合にも有効なノイズ除去法として交互 ノイズ消去法（ANC 法）を提案している.

\section{ANC の原理}

産業における光応用計測のみならず一般的な光計測のモデルと して，白熱電球光のフォトトランジスタによる計測が考えられ る.とのよらな計測を行らに当たって，信号線に伝導ノイズが発 生した場合におけるノイズ消去法の一例（ANC 法）を図 1 亿示 す.

図1のセンサは例えばフォトトランジスタを意味している.

この 2 つのンサの出力をアナログスイッチによって，周期的 に直列接続したりあるいは逆直列接続しており，信号線の伝導， イズは試験法 ${ }^{9}$ に基づいて加えている. こてで，2つのセンサの 特性が等しいものを用いると, 直列接続すると 2 倍の信号とノイ ズが，また逆直列接続だと，ノイズのみが伝送されるととにな

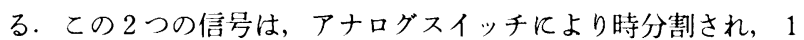
つの伝導線路で伝送され，AD変換器を通して計算機に取り込ま れる。そてで, 補間処理をすると共に, 。面列接続の信号值から逆 直列接続の信号值を差し引くととによってノイズ成分が取り除か れた所望の信号値を得る.

ANC 法の原理を図 2 亿示す.

困 2 (a)(A)の波形は直流ノイズを含んだ 2 倍の出力であり，2つ のセンサがアナログスイッチによって直列に接続されたときのも のである. 同図(B)の波形は, 直流ノイズのみの波形，すなわち逆 


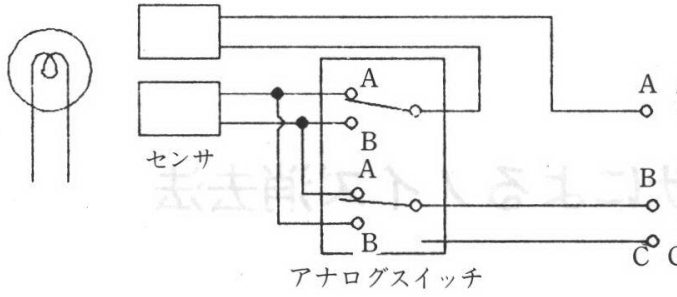

(a) 送信側

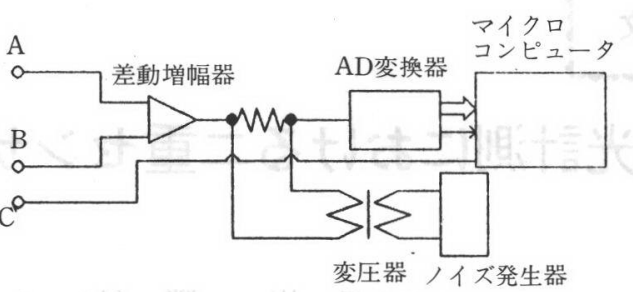

(b) 受信側

図 1 ANC 法による光計測システムのブロック図
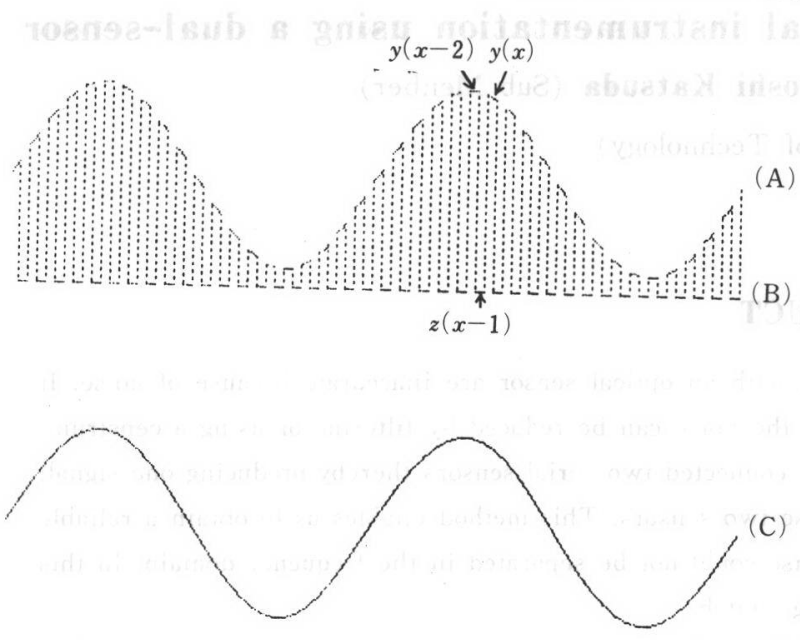

図 2 (a) ANC 法の原理図 (直流ノイズ印加時)
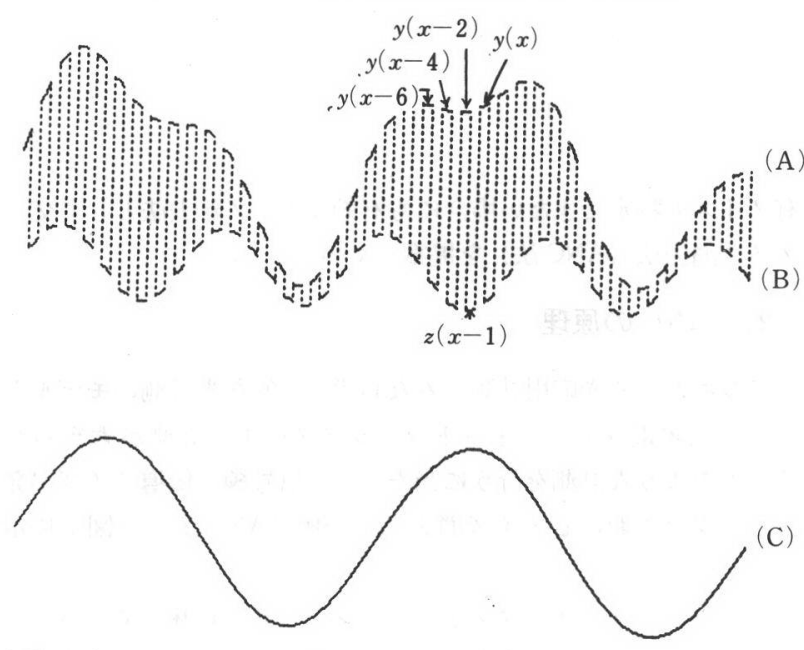

図 2 (b) ANC の原理図（正弦波ノイズ印加時）

直列接続のときの波形である. 同図(A)及び同図(B)のデータのない ととろは補間処理を施し，それぞれ同図(A)から同図(B)を差し引く 演算処理を行ったものが同図(C)の波形である. すなわち，乙の同 図(C)の波形が，ノイズが除去された所望の信号である。また，図 2 (b)に正弦波ノイズを印加したときのそれぞれの信号を示す. 同 図(A)の波形は, 正弦波ノイズを含んだ 2 倍の出力波形で, 歪んで レるととがわかる. 同図(B)がノイズのみの波形で正弦波が印加さ れているととがわかる. 同図(A)から同図(B)を差し引く演算処理を 行らと同図(C)の波形が，すなわち所望の信号が得られることにな る.なお, 正弦波ノイズを混入した場合の検証波形を図 4 及び図 6 に, 方形波ノイズを混入した場合の検証波形を図 7 にそれぞれ 示す.

\section{3. 実 験 結 果}

写真 1 亿示すよらな実験装置を試作した. 実験に使用したセン サとしては, 即応性フォトトランジスタを用い, 光源としては $100 \mathrm{~V}, 60 \mathrm{~W}$ の白熱電球を用いた. 白熱電球には, $60 \mathrm{~Hz}$ の商用周 波数を用いているため, センサ出力としては $120 \mathrm{~Hz}$ の正弦波が 得られる.

表 1 亿実験に使用した器具を示す.

データを演算処理するとをのフローチャートを図 3 亿示す. 図 3 (a)は一次補間の場合である。Xを離散時刻とするとき, 図 3 (a) と図 2 (a)より $Y A$ は $y(x)$ と $y(x-2)$ との平均値で, $Y S$ は実際 のデータ $z(x-1)$ から, 平均值 $Y A$ を差し引く演算処理であ る. 同図(b)はニュートン補間の場合である. 一次補間と異なり, 4 つの点から值のない点を推定し, 同図(a) と同様に演算処理を行 ったものである.

図 $4 \mathrm{~K}$, ノイズの周波数 $120 \mathrm{~Hz}$ ，スイッチ切り換え周波数 $10 \mathrm{KHz}$ ，一次補間を用的場合の結果を示す.

図 4 (a)がノイズを含んだ計測信号でノイズのために昰んで現れ

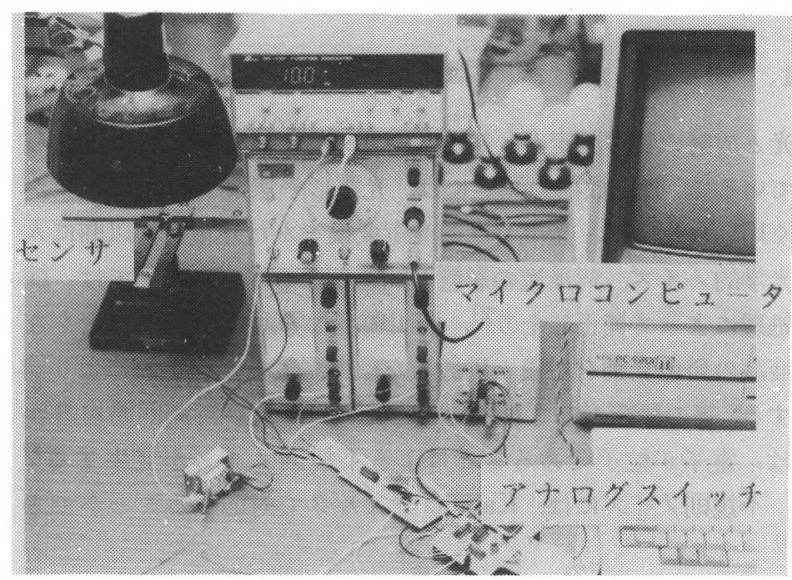

写真 1 ANC一法の実験装置

表 1 実験に使用した器具

\begin{tabular}{l|l|l|l}
\hline \multicolumn{1}{c|}{ 品 } & \multicolumn{1}{c|}{ 型 } & \multicolumn{1}{c|}{ メーカー } & \multicolumn{1}{c}{ 備 考 } \\
\hline センサ & TPS601 & 東 芝 & 即応性 \\
\hline アナログスイッチ & MPC801 & BURR-BROWN & \\
\hline 差動アンプ & 082 & JRC & \\
\hline AD 変換器 & ADC80 & BURR-BROWN & 12 bit \\
\hline マイクロコンピュータ & PC-9801 & NEC & \\
\hline 白熱電球 & & NEC & $100 \mathrm{~V} 60 \mathrm{~W}$ \\
\hline
\end{tabular}




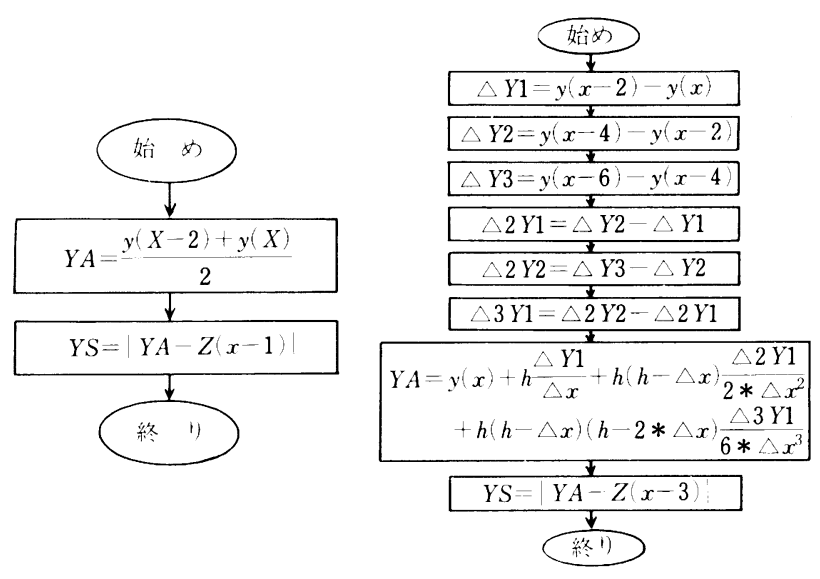

(A) 一次補間

(B) ニュートン補間
(A)

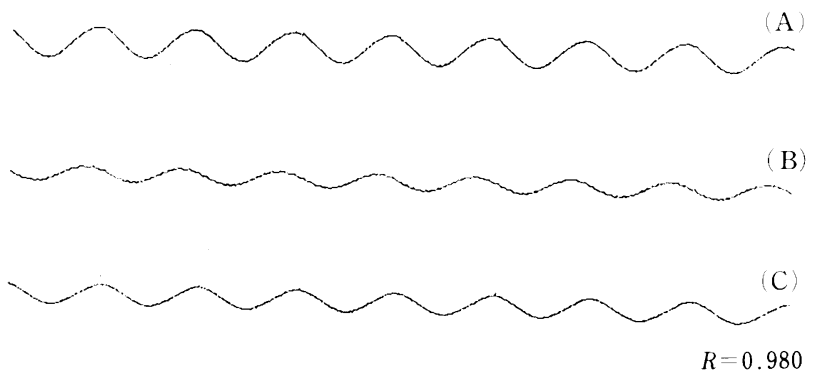

図 4 一次補間を用いたときの処理波形

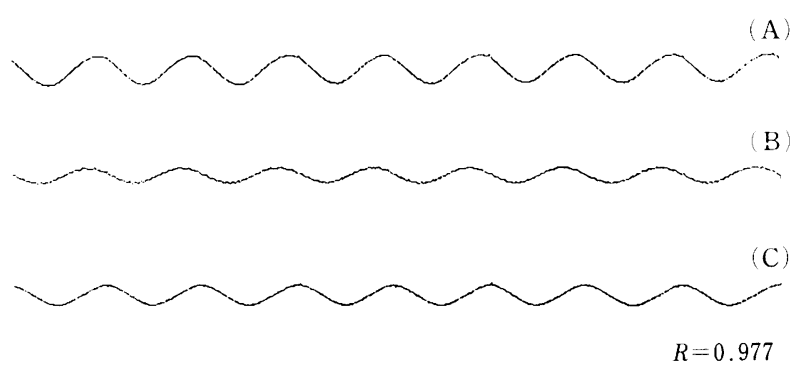

図 5 ニュートン補間を用いたときの処理波形

ている．同図(B)がノイズの信号でファンクションジェネレータを ノイズ発生器として用い，その出力を変圧器で昇压し所定のノイ ズ試験法により印加したものである．同図(C)が演算処理を施した 波形である。とこで，ノイズを印加しない場合の波形を真の波形 とし，とれと同図(C)との相互相関関数の值は，0.980を示した. 従って同図(C)の波形を実用的には真の計測信号（所望の信号）と 見てよいと考える.

同様に図 5 はデータに図 4 と同じ值を用い、ニュートン補間を 用々た結果を示す ${ }^{10)}$. 図 4 と同様，ノイズを印加しない場合の 波形を真の波形として，乙れと図 5 (C) との相互相関関数の值は 0.977 を示した. てれも，実用的には真の信号と見てよいと考元 る. 図 $6 \mathrm{~K}$ ，ノイズの周波数 $240 \mathrm{~Hz}$ 一定とし，切り換え周波数 を $10,8,5,3$ 及び $1 \mathrm{KHz}$ 亿変え，一次補間で処理したときの波形 を示す.

ここでは，図4のときと同様相互相関関数の值を右下にそれぞ れ示した. これによると切り換え周波数がノイズ周波数の 5 倍以 下になると，波形が崩れてきて相互相関も悪くなるととがわか

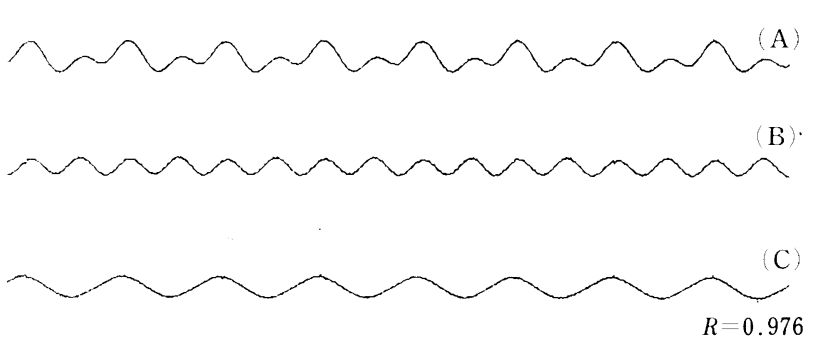

(a)切り換元周波数 $10 \mathrm{KHz}$ の時

(A)

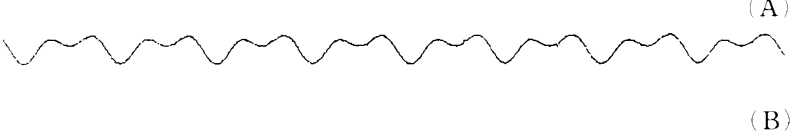

(B)
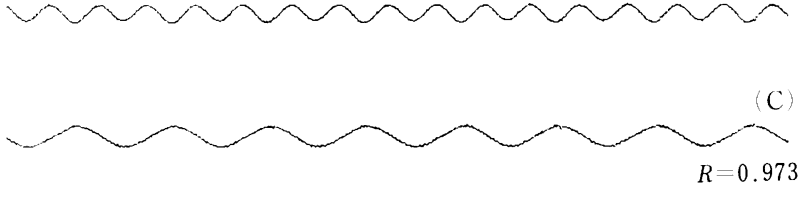

(b)切り換え周波数 $8 \mathrm{KHz}$ の時

(A)

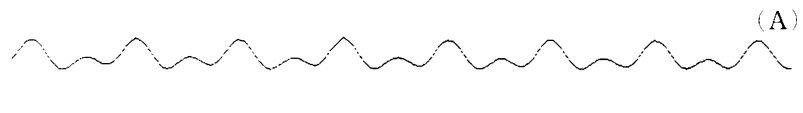

(B)

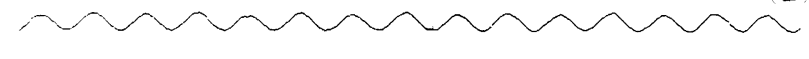

(C)

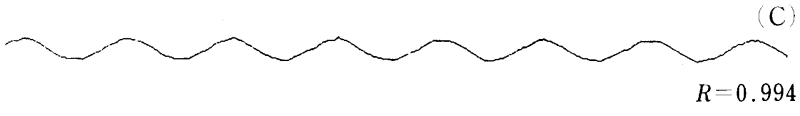

(c)切り換え周波数 $5 \mathrm{KHz}$ の)時 $R=0.997$

(d)切り換元周波数 $3 \mathrm{KHz}$ の時

$R=0.952$

(e)切り換元周波数 $1 \mathrm{KHz}$ の時

図6 切り換元周波数在変えたときの处理波形

る. 相関関数の值については, 周期ごとに多少のばらつきが生じ たため, 切り換え周波数 $5 \mathrm{KHz}$ の場合のデータ 25 個について統 計学的処理を行った．表 2 に検定に用いたデータを示す。また， 表 3 に計算に必要な值を示した. この表をもとに正規確率用紙に プロットするとほぼ一直線となり正規分布するととがわかった. この相関関数の值の有意性を有意水淮 $5 \%$ で検定した結果を示 
表 2 測 定 デ - 夕

\begin{tabular}{lrlll|l|l}
\hline & \multicolumn{2}{c}{$\vec{F}$} & \multicolumn{2}{c|}{ 多 } & Max. & Min. \\
\hline 0.979841 & 0.982959 & 0.981136 & 0.98473 & & 0.98473 & 0.979841 \\
0.986625 & 0.980531 & 0.98553 & 0.980352 & 0.980651 & 0.986625 & 0.980352 \\
0.983135 & 0.984238 & 0.982676 & 0.984634 & & 0.984634 & 0.982676 \\
0.981907 & 0.980512 & 0.984753 & 0.980762 & 0.984753 & 0.980512 \\
0.982189 & 0.989055 & 0.978401 & 0.987598 & 0.989055 & 0.978401 \\
0.977244 & 0.985747 & 0.982922 & 0.983172 & 0.985747 & 0.977244 \\
\hline
\end{tabular}

表 3 計 算 表

\begin{tabular}{|c|c|c|c|c|c|c|c|}
\hline 区 & 代表值 & 度数 $f$ & $u$ & $u f$ & $u^{2} f$ & 累皘度数 & 累積度数 96 \\
\hline $0.977 \sim 0.979$ & 0.978 & 2 & -2 & -4 & 8 & 2 & 8 \\
\hline $0.979 \sim 0.981$ & 0.980 & 6 & -1 & -6 & 6 & 8 & 32 \\
\hline $0.981 \sim 0.983$ & 0.982 & 6 & 0 & 0 & 0 & 14 & 56 \\
\hline $0.983 \sim 0.985$ & 0.984 & 6 & 1 & 6 & 6 & 20 & 80 \\
\hline $0.985 \sim 0.987$ & 0.986 & 3 & 2 & 6 & 12 & 23 & 92 \\
\hline $0.987 \sim 0.989$ & 0.988 & 1 & 3 & 3 & 9 & 24 & 96 \\
\hline $0.989 \sim 0.991$ & 0.990 & 1 & 4 & 4 & 16 & 25 & 100 \\
\hline 計 & - & 25 & - & 9 & 57 & - & $\ldots$ \\
\hline
\end{tabular}

$H_{0}: \mu=\mu_{0}\left(\mu_{0}=1.0\right)$ を $H_{1}: \mu \neq \mu_{0}$ に対して $\alpha=0.05$ で検定する。

$$
R:\left|t_{0}\right|=\frac{|\bar{x}-1.0|}{\sqrt{V / 25}} \geqq t(24,0.05)=2.064
$$

平均值: $\bar{x}=0.98272$

$$
\begin{gathered}
\text { 標準偏差 }: S=\left\{57-\frac{9^{2}}{25}\right\} \times \frac{1}{1000^{2}}=0.00005376 \\
\text { 分 散 }: V=0.00005376 \div 24=0.00000224 \\
\therefore\left|t_{0}\right|=\frac{|0.98272-1|}{\sqrt{0.00000224 / 25}}=57.6 \\
\therefore\left|t_{0}\right|=57.6 \geqq 2.064
\end{gathered}
$$

従って, 有意水準 5 \%で $H_{0}$ は东却される。

(A)
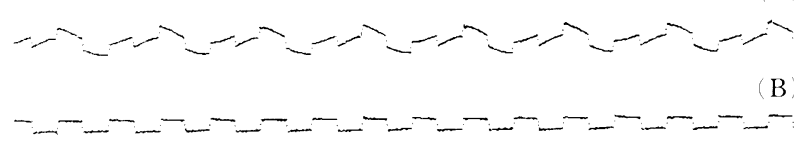

(C)

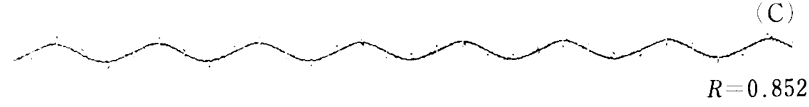

図 7 方形波ノイズ印加時の処理波形

A

B

$R=0.991$

図8带域制限白色ノイズを混人した場合の処理波形

す.

图 7 は，ノイズに方形波を加え，一次補間で処理したときの波 形を示す．とれを見ると，ノイズの方形波の立ち上がり立ち下が りの点で処理波形に補間誤差によるひげが現れるが，相関係数か らも実用的飞満足すべき計測信号と考えられる.

图 8 K，帯域制限白色ノイズを混入し，一次補間で処理したと きの波形を示す．白色ノイズは，微小電流でバイアスされたツェ
ナーダイオードの「ノイズ」を利用した。このノイズを $250 \mathrm{~Hz}$ のローパスフィルタにかけ, 带域制限白色ノイズとして混人し た.

この結果をみれば ANC 法処理前はノイズのために計測信号が 乱されているが，処理後は所望の計測信号が得られているてとが わかる.

\section{4. 結 論}

(1) 光計測において，信号線の伝導ノイズの周波数特性が光信 号と等しい場合であってもノイズ除去が可能な二重センサ 交互ノイズ消去法（ANC 法）を開発した.

(2) 二重センサ交互ノイズ消去法におけるスイッチの切り換え 周波数は，信号及び伝導ノイズの最高周波数の 5 倍以上で あれば実用上支障ないと考える。

(3) 交互に出現する 2 倍のセンサ出力值及び伝導ノイズ值の補 間法は，スイッチの切り換え周波数が低い場合は，一次補 間法よりも例えばニュートン補間法の方がやや好成績であ つたが，全般的には一次補間の実用性が確認された。

(4) 二重センサは, 人力に対する出力がバランスするように取 り付けると共に, 分光感度特性, 温度特性等の諸特性が等 しいものを選定する必要がある。

(5) ANC 法では光センサ出力は正しい信号として扱らので, 背景光や吸収・散乱等の光センサに混入するノイズは除去 できない。このような場合は, ロックイン増幅器 ${ }^{11)}$ など と組み合わせるなどの方法が考えられる。

照明学会誌 第 74 巻 第 10 号 平成 2 年 


\section{謝 辞}

本研究に終始ご援助在賜った森本祐治技官ならびに卒業研究と して熱心にご協力下さった高橋伸樹君，渡部宣哉君上伊藤義文君 ならびにご支援下さった旭計器厂。業(侏深町社長に感謝致します。

参 考文 献

(1) 栗岡，西：光の放射の物理測定（CIE ベニス大会特集，第 2 部会）照学誌, 72-1（昭 63）11１3

（2）相田，芹田，中島，山下，永村：背景光の影響を補正した PDS カメラによる三次元座標検出法, 電学論 C, 107-7 (昭 62) 632 639

(3) Morimoto, Y., Mine, K. and Seki, T.: A Method of Hierarchical Diagnosis of Thermal Process Using Liquid Crystal, IMEKO XI, Houston, Intelligent Systems, 88-a23, (1988) $183 \sim 190$

(4) A. アンブロジィ著, 高木・越後訳：電子ノイズ, 繁学出 版 (1988)
(5) Bozic, S. M.: Digital and Kalman filtering, Edward Arnold (1981)

(6) Kemerait, R. C. and Childers, D. G.: Signal Detection and Extraction by Cepstrum Cepstrum Techniques, IEEE Trans. on Information Theory, IT-18, 6, (1972) 745 759

(7) Widrow, B. and Winter, R.: Neural Net for Adaptive Filtering and Adaptive Pattern Recognition, IEEE COMPUTER, 21, 3, (1988) 25 39

(8) Mine, K., Ogawa, K., Yamada, M., Morimoto, Y. and Jinnouchi, Y.: A Method for the Removal of the Specific Noises, IMEKO XI, Houston, Applications, 88-D3, (1988) $55 \sim 62$

(9) SICE 産業委員会編：ディジタルシステム耐ノイズ設計ガ イド昭和 63 年 7 月, 170 - 180

(10) 戸川隼人著：数值計算法, コロナ社（1981）

(11) 石井 泰：測定と依号処理，計測と制御，15-（昭51）76 $\sim 82$ 